\title{
Does Service Innovation Matter in High-Tech Industry?
}

\author{
Chao-Hung Wang
}

\begin{abstract}
Service innovation has been found to be a major driver of innovation performance in service contexts. But this issue raises questions concerning the extent to which the relationship between market orientation and innovation performance holds in the high-tech industry. Relatively little research has examined how market orientation contributes to innovation performance through service innovation. We here report an empirical study of 235 Taiwanese high-tech firms to examine the influence of market orientation on service innovation and innovation performance.A noteworthy finding is that the impacts of customer orientation and competitor orientation on innovation performance are fully mediated by service innovation. However, service innovation does only partially mediate the relationship between inter-functional orientation and innovation performance. The findings of this study should help managers consider appropriate service innovation in high-tech industry.
\end{abstract}

Keywords: market orientation; innovation performan ce; service innovation.

Cao-Hung Wang, I Ling Tung Road, Nantun, Taichung, 40852, Taiwan, R.O.C. Phone: 886-4-2389-2088 Ext.3522.

Fax: 886-4-2389-5293. E-mail: chw@mail.Itu.edu.tw.

ISSN: 07 I8-2724. (http://www.jotmi.org)

Journal of Technology Management \& Innovation (c) Universidad Alberto Hurtado, Facultad de Economía y Negocios. 


\section{Introduction}

Service innovation, a concept that has long been studied in service management research, is a part of the basis for different issues in the service industry such as customerinvolvement (Bendapudi and Leone 2003), knowledge transformation (Muller and Zenker 200I), cooperation (Mention 20II), innovation patterns (Chang et al. 20I2), and servicespecific measurement (Hipp and Grupp 2005). Beyond the service industry, researchers have recently begun to examine the high-tech industry within the contexts of co-production (Chen et al. 20l I), small-and-medium enterprises (SMEs) (Amara et al. 2008), knowledge acquisition (Cassiman and Veugelers, 2006), and customer integration (Straub et al. 2013). Service innovation was first discussed by Vandermerwe and Rada (1989), who refer the process of creating value by adding services to product offering. This process is seen as being driven by ever more complex customer demands. Gronroos (1990) defines service innovation as the new service product, the new procedure for producing or delivering a service. Service innovation thus refers to the development of novel ideas and offerings for improving service delivery processes (Sundbo and Gallouj 2000). Service innovation is of particular importance in the high-tech industry because it becomes a major source of competitive advantage for high-tech firms cultivating the ability to use both knowledge obtained from customers, competitors and their own coordination capabilities to create meaningful and distinctive services.

The study of service innovation in the high-tech sector, however, is relatively recent and is clearly under-represented in the innovation literature. In fact, until the early 2000 s, this sector was largely neglected. Most high-tech firms were mainly concerned with technological innovation, which was believed to be the main engine of a firm's growth; and furthermore, high-tech firms were traditionally regarded as being less intensive in service innovation. But when service innovation was freshly studied in the manufacturing industry sector by researchers such Pires, Sarkar, and Carvalho (2008); Santamaría et al. (20I2), it can be noted that service innovation would be appropriate for understanding how high-tech firms identify such innovation. Following this logic, we argue that service innovation is equally, if not more, relevant for understanding innovation performance in the high-tech industry level. In fact, failing to develop service innovation may damage a firm's innovation performance. For example, just seven years after Google's founding, it has achieved a valuation of market performance that substantially surpasses it competitors (e.g., Yahoo). Google offers and integrates the most popular Internet applications. The quality of the search results depends largely on the user-oriented by its innovation; a novel search engine links skills, know-how, information, and data. Although this example clearly illustrates the important role of service innovation in high-tech sector, existing research on service innovation in this area has been scanty and incomplete. The current study search is intended to cover these weaknesses found in the previous literature. Along with SI, market orientation (MO) has also been discussed in the context of high-tech firm's innovation (e.g., Jiménez-Jimenez et al. 2008; Laforet 2009;Aldas-Manzano et al. 2005), but the links between $M O$ and innovation are far from being fully explained (e.g., Lukas and Ferrell, 2000, Zhou et al., 2005). The relationship between $M O$ and innovation, in particular, has obtained very mixed findings and arguments in the literature. Though some scholars suggest that MO leads to successful innovation (Deshpandé et al. 1993; Slater and Narver 1994), others argue that MO has negative consequences for innovation performance because it leads to the development of uncompetitive "me-too" products rather than real innovations (Atuahene-Gima 1996; Gatignon and Xuereb 1997). Consequently, empirical research has found no evidence of any significant relationship between $\mathrm{MO}$ and the question of innovation whether MO facilitates or impedes innovation remains unanswered (Zhou et al. 2005). We thus argue that scholars need to clarify these disparate findings and contentions to investigate how MO could influence a firm's innovation performance.

This paper examines the ways that MO and service innovation both contribute to our understanding of innovation performance in high-tech industries. Since empirical research on the link between these three concepts is still limited, this paper empirically studies the relationships between MO, service innovation, and innovative performance together in a single model. The paper begins with a discussion of $M O$ in the area of innovation performance, followed by a discussion of the nature of service innovation in the area of innovation performance in high-tech industry. Figure I shows a causal model to explain the relationship between these variables, and this is followed by a test of the model using a sample of 235 high-tech firms. Finally, the findings are presented along with managerial and academic implications, limitations of the study and recommendations for future research.

\section{Theoretical Development and Hypotheses $\mathrm{MO}$ and Innovation Performance}

MO has been constant research focus over the past twenty years. Among the many contributions that have emerged, two frameworks for studying $\mathrm{MO}$ can be distinguished in the literature. On the one hand, the work of Kohli and Jaworski (1990) is based on the three basic pillars of marketing (i.e., generation, dissemination and responsiveness to market intelligence). On the other hand, the work of Slater and Narver (1994) stresses that MO is an organizational culture made up of three behavioral components: customer orientation, inter-functional orientation, and competitor orienta- 


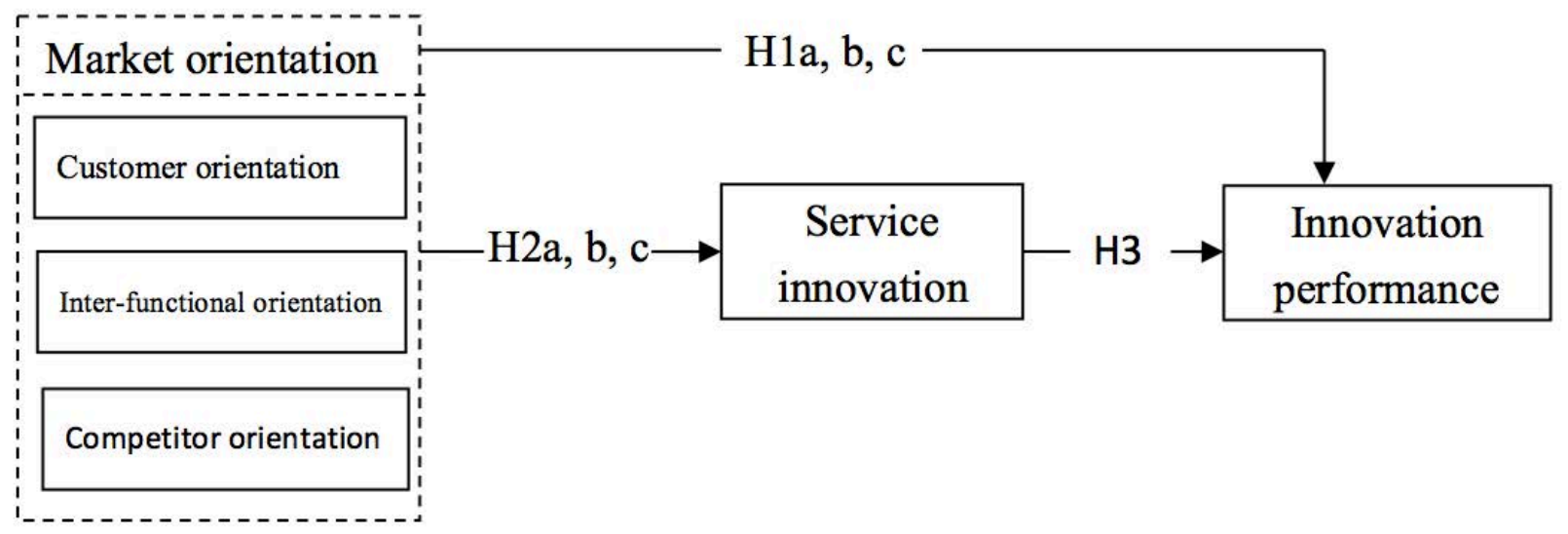

Figure I.The proposed model

tion. Together with the concept of $\mathrm{MO}$, the concept of $\mathrm{MO}$ is referred to the generation and dissemination of market information inter-functional coordination of this information directed at creating value for customer (Aldas-Manzano et al. 2005; Keskin 2006).

MO can be viewed as organizational behaviors related to the external market environment (Augusto and Coelho 2009). Because the customer orientation focuses on developing information about extreme external market changes, $\mathrm{MO}$ high-tech firms are arguably well positioned to anticipate and respond to the emerging needs of their customers (Olsen and Welo 20II) and may also be more likely to innovate successfully. In addition, an MO high-tech firm is presumed to have superior market-sensing and customer-linking capabilities, and these capabilities are presumed to assure them of higher innovation performance than firms that have less MO (Baker and Sinkula 2007).

To facilitate novelty within a high-tech firm, inter-functional coordination entails the collaboration of different units that can facilitate the generation, collection, and dissemination of market intelligence pertaining to innovation development across functional areas (Auh and Menguc 2005). In addition, developing a new technology requires inter-functional collaboration to resolve technical and market issues and to do so rapidly (Cambra-Fierro et al. 20I I). It involves the sharing of new ideas, resolution of problems, and innovative responsiveness (Akman and Yilmaz 2008). Thus, the rapid dissemination of new intelligence to functional units and coordinating the units' synergistic activities is required in order to foster innovation performance.

Competitor orientation can enhance a high-tech firm's ability to analyze and respond to competitors' strategies, thus allowing it to offer innovative products that differ from those of its competitors (Zhou and Li 2007). Furthermore, scanning competitors can help high-tech firms identify emerging novel substitutes. This information can then be incorporated into innovative strategies for determining the timing for the market entry of innovative products. Thus, without good knowledge of the competition, a high-tech firm's managers cannot identify the best courses of action to enhance their innovation performance. Accordingly, we propose the following hypothesis.

Hla: Customer orientation has a positive impact on innovation performance.

HIb: Inter-functional orientation has a positive impact on innovation performance.

HIc: Competitor orientation has a positive impact on innovation performance.

\section{Market Orientation and Service Innovation}

Innovation performance is more difficult to achieve when innovation that used to create a firm's domain is easily subject to imitation or substitution by competitors (Laursen and Salter 2006; Tsai 2009). Technical change is strongly attributed to innovation performance, and the use of the same definition may fail to capture a majority of innovation performance unless innovation performance is further defined. In this study, innovation performance refers to results for firms in terms of the degree to which they actually introduce new goods or substantially improve their services in the market. This definition expands the research limitation of innovation performance in prior studies (e.g.,Wang 20I I). In other words, this redefinition of innovation performance in the service innovation sense focuses on both the technical aspects of innovation and the introduction of new services into the market.

\section{Mediating Role of Service Innovation}

Accordingly, to have untinned innovation performance, service innovation must be considered by firms in high-tech industries, since they tend to overlook the service aspects of high-tech products, a condition referred to as service myo- 
pia (Bateson and Hoffman 20II). For example, Apple may view the iPhone as being a high-tech product and primarily focus on the iPhone itself. High-tech products, however, have very short product life cycles because of their technology is quickly diffused (Adner and Levinthal 200I). However, a service innovation view recognizes that the company is providing the customer with a friendly experience that has been deliberately created for the targeted customer (Tsiotsou, 2010; Song et al. 2009). Moreover, adding service aspects to a high-tech product can differentiate a high-tech firm from its competitors, and by doing so, produce opportunities for the high-tech firm to dramatically increase its innovation performance.

This scenario does not evoke service innovation as a principal explanation for the effect of MO on innovation performance. We have previously suggested that service innovation allows high-tech firms to leverage their MO. High-tech firms can only make value propositions; the MO must interpret and co-create that value (Michel et al. 2008). Firstly, service innovation generally involves many more customer experiences than does the high-tech product itself, and these experiences can directly influence the customer's assessment of value that helps to create innovation performance (Voon 2006; Sin et al. 2002). Secondly, we have also demonstrated relationships to service innovation integration, specifically, in the high-tech firm's manufacturing and service roles. Since innovation performance exists because of the division of labor, so the integration of different knowledge sources must be part of service innovation co-creation. In other words, the distinction between good products and service activities becomes increasingly unnecessary in a high-tech firm (Armbruster et al 2008; Lay et al. 2010). Thus, offering service innovation is driving firms to improve their technologically-based products in order to pursue the breakthrough of product innovation (Santamaría et al. 20I2).

Finally, in a fiercely competitive environment, successful hightech firms must have service innovation sensing abilities that routinely gather new information from a variety of competitors' sources to utilize as input for expanding their strategy mix. Novel service information of competitors allows better prediction of the competitors' possible future strategies. Furthermore, lack of this knowledge of competitors' service innovation reduces innovation performance since a high-tech firm would lacks confidence to accurately predict competitors' reactions to possible strategies (Morgan and Berthon 2008). We thus expect that the simultaneous development of a high-tech firm's $M O$ and service innovation will reinforce a high-tech firm's innovative capability, and in turn, improve its innovation performance (Spohrer and Maglio 2008). This implies that $M O$ is expected to positively influence innovation performance via its positive impact on service innovation. Therefore, we posit the following hypothesis.
$\mathrm{H} 2 \mathrm{a}$ : Service innovation mediates the relation between customer orientation and innovation performance.

$\mathrm{H} 2 \mathrm{~b}$ : Service innovation mediates the relation between inter-functional orientation and innovation performance.

$\mathrm{H} 2 \mathrm{c}$ : Service innovation mediates the relation between competitor orientation and innovation performance.

\section{Service Innovation and Innovation Performance}

From the perspective of traditional technology innovation theory, it remains difficult to understand what service innovation is. Service innovation differs from the traditional technological innovation in following ways (Vargo and Lusch 2008). Firstly, the service delivery staff, including service providers and contact personnel are part of the customer experience and thus part of the innovation (Flint et al. 2002). The most successful high-tech firms will not be those who focus exclusively on their own competitive advantages (e.g., technological innovation). On the contrary, high-tech firms that incorporate customers' experiences into the firm's innovation will be strong in innovation performance even in the future (Moller et al. 2008,Vargo and Lusch 2004).

Through mutual investments and adaptations, a high-tech firm and its customers can produce more effective solution either one on its own, and this service innovation strategy adds value to the existing market solutions. Most service innovation requires a high degree of integration between the high-tech firm and its customers, especially in a knowledge-intensive sector. A more new approach is to offer the customer not the technology-based product per se, but rather the goal that the purchase of the high-tech product will ultimately fulfill the functionality it will provide such as Cloud computing (Blazevic and Lievens 2008; Abramovici and Bancel-Charensol 2004). For example, Apple iTunes is a digital media player application, and the actual value of the innovation comes from the services that allow customers to connect to the online store to download, purchase, and share digital products. Apple has successfully used service innovation to break the traditional modes of the high-tech industry (Paswan et al. 2009).

Secondly, service innovation can also help increase the demand for technology-based products, thus making them potentially important for the competitiveness of high-tech firms. These high-tech firms offer new services to improve the acceptability, functionally, and performance of existing goods (Gebauer et al. 2010). In other words, customers are motivated by achieving a positive change in their business or their life through the service innovation offered by the high-tech firm. This leads to the customers' willingness to pay a premium for new features. Adding new services to a 
technology-based product is a way to differentiate a hightech firm from its competitors and to sustain its innovation performance (Gebauer et al. 2005). Therefore, we posit the following hypothesis.

H3: Service innovation has a positive impact on innovation performance.

\section{Methodology Sample and Data}

This study focuses on the high-tech sector because the hightech firms involved have been considered to be mostly driven by service innovation. In addition, the high-tech industry is appropriate because the rapid changes in its market and technological development in these sectors make service innovation in technological-based product exchange particularly salient. The sample data was drawn from the top I,000 Taiwanese manufacturing firms, which is compiled annually by Commonwealth. The original observations of 1,000 firms from the Commonwealth list have been used to support previous research (Gatignon and Xuereb 1997; Zhou et al. 2009; Wang 20I4; Jaw et al. 2010).We exclude the 300 small and traditional manufacturing firms such as foods, beverage, textile and furniture, etc. since these firms usually have less of the innovative activities and formal organizational function. The remaining Taiwanese high-tech firms have incorporated service innovation practices into their innovative activities. Thus this sample is representative of not only the high-tech industry but also of businesses in other service industries such as logistics, transportation, etc.

Table I summarizes the characteristics of the respondent firms. A total of 700 questionnaires were distributed and 235 responses were received for a response rate $33.5 \%$. We conducted a chi-square test to check for non-response bias by comparing the responses with the profile of the sample for characteristics such as industry, capital, and number of employees. These tests showed no significant difference $(p<0.05)$, which suggests that non-response bias was not a problem in this study. We further compared early and late respondents in terms of the means of all items using the t-test (Armstrong and Overton 1977). These comparisons did not reveal any significant differences, indicating that no systematic differences were found between early and late respondents.

If a significant amount of common method bias exists in the data, then a factor analysis of all the variables in the model will generate a single factor that accounts for most of the variance (Podsakoff 2003). The Harman (1976) one-factor test was also performed. The results show that there were several factors with an eigenvalue greater than one using un-rotated factor analysis, and the first factor explained only $17.9 \%$ of the variance in the data, which suggests that the data were not subject to common method bias.

Table 2 provides an overview of the characteristics of the sample in terms of company age, number of employees, and company capital. The largest group of firms had been established between $3 \mathrm{I}$ and 40 years (33.2\%), there were $27.2 \%$ between $2 \mathrm{I}$ and 30 years, and the smallest group of firms was between $\mathrm{II}$ and 20 years (5.1\%). The number of employees in the largest portion of firms ranged from 101 to 500 (33.6\%); with $18.3 \%$ of the firms having over 2,000 employees. In addition, $35.7 \%$ of the firms had capital exceeding 2,000 million NTD. Table 3 summarizes the characteristics of the respondents. Since service innovation is likely to be developed by the marketing, planning, and business departments, managers were chosen from these fields. Among the 235 respondents, $30.21 \%$ were responsible for the business department and $25.53 \%$ in other categories. The highest position of respondents was that of CEO, comprising $15.31 \%$ of the total, and $33.61 \%$ of the respondents were department managers, $28.08 \%$ of the respondents considered that their job was related to service innovation (e.g., R\&D engineer and general manager, etc.). The largest portion of respondents (31.48\%) claimed that they had worked at the company from $7-10$ years, and the fewest respondents $(8.51 \%)$ had worked less than 3 years.

\begin{tabular}{|l|l|c|l|}
\hline \multicolumn{1}{|c|}{ Industry-sector } & SIC code & Number of firms involved in this study & \multicolumn{1}{c|}{ Number of Response } \\
\hline Computer equipment & 3571 & 118 & 48 \\
\hline Electronic equipment & $364 I$ & 160 & 36 \\
\hline Communication equipment & 3663 & 88 & 30 \\
\hline Machinery equipment & $354 I$ & 160 & 32 \\
\hline Semi-conductor and related & 3674 & 52 & 28 \\
\hline Others & & 122 & 61 \\
\hline Total & & 700 & 235 \\
\hline Response rate & & & $33.5 \%$ \\
\hline
\end{tabular}

Table I. Industry-sector distribution of the sample

ISSN: 07I 8-2724. (http://www.jotmi.org)

Journal of Technology Management \& Innovation (c) Universidad Alberto Hurtado, Facultad de Economía y Negocios. 


\section{Measurement}

The theoretical constructs in the study were measured using multi-item scales. The measurement instruments were taken from the literature when available. However, since we did not find a precise or definitive set of items, we made some minor modifications to suit our particular case in some instances.

\begin{tabular}{|l|c|l|}
\hline \multicolumn{1}{|c|}{ Characteristics } & Number of response & Percentage \\
\hline Company age & & \\
\hline $0-10$ years & 35 & $14.8 \%$ \\
\hline$I I-20$ years & 12 & $5.1 \%$ \\
\hline $21-30$ years & 64 & $27.2 \%$ \\
\hline $31-40$ years & 78 & $33.2 \%$ \\
\hline$>4 I$ years & 46 & $19.5 \%$ \\
\hline Number of employees & & \\
\hline$I-100$ & 32 & 13.7 \\
\hline $10 I-500$ & 79 & $33.6 \%$ \\
\hline $50 I-1,000$ & 54 & $23 \%$ \\
\hline$I, 000-2,000$ & 27 & $7.1 \%$ \\
\hline$>2,000$ & 43 & $18.3 \%$ \\
\hline Company capital (million NTD) & & \\
\hline$>=100$ & $4 I$ & $17.4 \%$ \\
\hline $10 I-500$ & 23 & $9.8 \%$ \\
\hline $50 I-1,000$ & 13 & $5.5 \%$ \\
\hline $1,000-2,000$ & 74 & $31.5 \%$ \\
\hline$>2,000$ & 84 & $35.7 \%$ \\
\hline
\end{tabular}

Table 2. Characteristics of sample

\begin{tabular}{|l|c|l|}
\hline \multicolumn{1}{|c|}{ Characteristics } & Number of respondents & \multicolumn{1}{|c|}{ Percentage } \\
\hline Department & 22 & \\
\hline CEO office & 13 & $9.36 \%$ \\
\hline Planning & 69 & $5.53 \%$ \\
\hline Marketing & 71 & $29.36 \%$ \\
\hline Business & 60 & $30.21 \%$ \\
\hline Others (e.g., staff of CEO office) & & $25.53 \%$ \\
\hline Respondent title & 36 & \\
\hline CEO & 79 & $15.31 \%$ \\
\hline Manager & 54 & $33.61 \%$ \\
\hline Vice manager & 66 & $22.97 \%$ \\
\hline Others (e.g., engineer) & & $28.08 \%$ \\
\hline Tenures with company & 20 & \\
\hline$<3$ years & 36 & $8.51 \%$ \\
\hline $4-6$ years & 74 & $15.31 \%$ \\
\hline $7-10$ years & 56 & $31.48 \%$ \\
\hline II-20 years & 49 & $23.82 \%$ \\
\hline$>21$ years & $20.85 \%$ \\
\hline
\end{tabular}

Table 3. Distribution of respondents

ISSN: 07 I8-2724. (http://www.jotmi.org)

Journal of Technology Management \& Innovation (c) Universidad Alberto Hurtado, Facultad de Economía y Negocios. 


\section{Dependent variables}

Prior research has used many indicators of innovation measuring innovation performance by combining several dimensions related to the levels of innovation activities such as R\&D inputs, patent counts, patent citations, or counts of new product announcements (Zeng et al. 20 I 0; Liu and Buck 2007; Li and Tang 2010). But recently some scholars have questioned the advantage of using these indicators to measure innovation performance (e.g., Hagedoorn and Cloodt 2003). Thus, this study uses self-reported data as a valid indicator. Subjective innovation performance measures are appropriate for use because they have been shown to be well correlated to objective measures of innovation performance (Dess and Robinson 1984; Slater and Narver 1994); moreover, subjective measures have been used in prior MOperformance studies (Jaworski and Kohli 1993; Cheng and Krumwiede 20I2).

According to the definition of innovation performance, the measurement must include the achievement from technology to service. The six items of innovation performance therefore cover the measurement of innovation performance of both product and service processes. We used six items to assess the innovation performance, and these items evaluate into the multiple facets of innovation performance incorporated in our definition, including service, product, and process. Respondents expressed their level of agreement on a 7-point scale (from I=disagree strongly to $7=$ agree strongly). This self-reported data have also been widely adopted by prior research (Xavier Molina-Morales et al. 20II; Keeble 1997).

\section{Independent Variables}

Service innovation is operationalized as the firm either introduces new services into the market or significantly improves existing services. Previous studies by Cheng and Krumwiede (20I2), and by Chen et al. (20II), Avlonitis et al. (200I) provided guidance in developing items, and we used six items to measure the construct of service innovation.
There is some debate as to whether MO is best measured from the viewpoint of the firm itself or from that of the customer, though most studies are based on the former.Accordingly, we measured $\mathrm{MO}$ from the point of view of the subject firm. Based on the MKTOR scales (Narver and Slater 1990), we decided to use a modified twelve-item version of the MO scale. Specifically, we used a list of items for each of the three dimensions of MO: competitor orientation, customer orientation, and inter-functional orientation. All items are listed in the Appendix.

\section{Measure Validation}

Measure validation began with exploratory factor analysis (EFA) and reliability analyses to purify the scales and ensure consistency of the items. The analysis revealed that one item for innovation performance and three items for MO were not consistent with the scales. After deletion of these items, we considered a confirmatory factor analysis (CFA) to assess construct reliability and uni-dimensionality. The results of CFA for measure validation of the model fit for the CFA was reasonable (Hair 2006), with a chi-square of 334.29(df=149), and a RMSEA of 0.065 and CFI of 0.918 , Standardized item loadings for all constructs were statistically significant $(p<0.01)$.

The construct reliabilities ranged between 0.78 and 0.89 , and the average variance extracted (AVE) for the measures ranged from $51 \%$ to $62 \%$, meeting standards accepted in the literature (Nunnally 1994). Discriminant validity was evaluated through the CFA of construct pairs. This study computed the AVE and compared it with the variance that each factor shared with the other factors in the model. Table 4 shows the results that all the diagonal elements representing the square root of the AVE are greater than the highest shared variance (the off-diagonal correlations). This method has been widely used by prior studies (e.g., Kandemir et al. 2006).

\begin{tabular}{|l|r|r|r|r|r|r|r|}
\hline & Mean & S.D. & I & 2 & 3 & 4 & 5 \\
\hline I. customer orientation & 5.79 & 0.087 & 0.7 I & & & & \\
\hline 2. Inter-functional orientation & 5.58 & 0.073 & 0.388 & 0.76 & & & \\
\hline 3. competitor orientation & 5.53 & 0.074 & 0.454 & 0.486 & 0.74 & & \\
\hline 4. Service innovation & 5.28 & 0.062 & 0.240 & 0.309 & 0.029 & 0.78 & \\
\hline 5. Innovation Performance & 4.29 & 0.069 & 0.332 & 0.392 & 0.389 & 0.336 & 0.75 \\
\hline
\end{tabular}

Table 4. Descriptive statistics and correlations

a. ${ }^{*}<<.05, * * p<.01, * * * p<0.001$ b. Numbers in the diagonal are the square root of AVE.

ISSN: 07 I8-2724. (http://www.jotmi.org)

Journal of Technology Management \& Innovation (c) Universidad Alberto Hurtado, Facultad de Economía y Negocios. 


\section{Results}

We estimated the structural model by AMOS 17.0 using the maximum likelihood estimation method. Table 5 identifies the overall and increment fit statistics of the theoretical structural model. The overall fit statistics of Model I-3 indicate an adequate model fit. $\mathrm{HIa}-\mathrm{C}$ predict positive relationships between three sub-constructs of $\mathrm{MO}$ and innovation performance. The path coefficients are found to be significant and positive [see Model I, Table 5], so Hla-c are supported which are consistent with previous studies (e.g., Atuahene-Gima 1996; Vázquez et al. 200I). Atuahene-Gima (1996) proposed an empirical study of 158 manufacturing and 117 service firms in Australia to examine the influence of $M O$ on innovation performance, finding that $M O$ makes a significant contribution to innovation performance. Similarly,Vázquez et al. (200I) verified empirically that MO high-tech firms obtain significantly better results in innovation performance.
The results support $\mathrm{H} 2 \mathrm{a}-\mathrm{c}$, since the three sub-constructs of MO positively influences the service innovation [see Model 2, Table 5]. This finding agree with studies that have posited that $M O$ is the facilitation and generation of positive outcomes that service innovation regardless of technologicallybased offering or service processes (e.g., Song et al. 2009; Alam 2006; Benner and Tushman 2003). The study examines mediation in the following way. Firstly, the link between service innovation and innovation performance [see Model 3, Table 5] is significant, so H3 is supported. Secondly, MOinnovation performance was added with the link of service innovation-innovation performance simultaneously included and found customer orientation $(\beta=0.149, t=0.861, p>0.1)$ and competitor orientation $(\beta=0.103, t=0.410, p>0.1)$ to be insignificant, suggesting the full mediating role of service innovation. Inter-functional orientation $(\beta=0.667, t=9.39$, $\mathrm{p}<0.0 \mathrm{I}$ ), which is smaller than that of Model I when service innovation is excluded, are statistically significantly. Thus, the results provide evidence for the partial mediating role of service innovation in the link between inter-functional orientation and innovation performance.

\begin{tabular}{|c|c|c|c|c|c|c|}
\hline \multirow{2}{*}{ Testing steps in mediation model } & \multicolumn{2}{|l|}{ Model I } & \multicolumn{2}{|l|}{ Model 2} & \multicolumn{2}{|l|}{ Model 3} \\
\hline & Coefficients & t values & Coefficients & $\mathrm{t}$ values & Coefficients & $\mathrm{t}$ values \\
\hline \multicolumn{7}{|l|}{ Testing Step I } \\
\hline \multicolumn{7}{|l|}{ Outcome: Innovation performance } \\
\hline Predictor: customer orientation $(\mathrm{HIa})$ & $0.893 * * *$ & 11.101 & & & & \\
\hline$(\mathrm{HIb}) \quad$ Inter-functional orientation & $0.855 * * *$ & 10.894 & & & & \\
\hline competitor orientation $(\mathrm{HIc})$ & $0.904 * * *$ & 12.935 & & & & \\
\hline \multicolumn{7}{|l|}{ Testing Step 2} \\
\hline \multicolumn{7}{|l|}{ Outcome: Service innovation } \\
\hline Predictor: customer orientation $(\mathrm{H} 2 \mathrm{a})$ & & & $0.629 * * *$ & 9.527 & & \\
\hline$(\mathrm{H} 2 \mathrm{~b}) \quad$ Inter-functional orientation & & & $0.149 * *$ & 2.397 & & \\
\hline competitor orientation $(\mathrm{H} 2 \mathrm{c})$ & & & $0.822 * * *$ & 9.305 & & \\
\hline \multicolumn{7}{|l|}{ Testing Step 3} \\
\hline \multicolumn{7}{|l|}{ Outcome: Innovation performance } \\
\hline Mediator: service innovation $(\mathrm{H} 3)$ & & & & & $0.337 * *$ & 6.712 \\
\hline Predictor: customer orientation & & & & & 0.149 & 0.861 \\
\hline Inter-functional orientation & & & & & $0.667 * * *$ & 9.39 \\
\hline Competitor orientation & & & & & 0.103 & 0.410 \\
\hline \multicolumn{7}{|l|}{ Overall fit } \\
\hline$\% 2$ & 157.808 & & 164.281 & & 319.147 & \\
\hline df & 66 & & 79 & & 157 & \\
\hline RMSEA & 0.067 & & 0.048 & & 0.040 & \\
\hline GFI & 0.909 & & 0.92 & & 0.915 & \\
\hline NFI & 0.921 & & 0.95 & & 0.913 & \\
\hline IFI & 0.922 & & 0.93 & & 0.975 & \\
\hline
\end{tabular}

Table 5. Testing mediator effects using structural equation model. ${ }^{*} p<.05,{ }^{*} \mathrm{p}<.01,{ }^{* * *} \mathrm{p}<.00 \mathrm{I}$

ISSN: 07I 8-2724. (http://www.jotmi.org) 


\section{Discussion}

Our interest in investigating the role of $M O$ in innovation performance was triggered by service innovation in hightech settings. This study extends prior studies (e.g., Deshpandé et al. 1993; Lukas and Ferrell 2000; Zhou et al. 2005) that report $\mathrm{MO}$ as a direct antecedent to performance but fail to provide compelling argument as to why it has such impact. One interesting finding is that three sub-constructs of MO have a strong direct effect on innovation performance, but two of effects of $\mathrm{MO}$ are insignificant when mediated by service innovation.

Many of our findings offer guidance to technological management practitioners, since by elaborating our conceptual model, we offer a rich set of results. The role of $\mathrm{MO}$ in affecting organization performance is well discussed in the organization literature (Kirca et al. 2005; Hult and Ketchen 200I; Baker and Sinkula 1999). But what is less understood is how $\mathrm{MO}$ affects innovation performance rather than market, financial, organizational performance, etc. Our findings suggest that a major concern is the development of $\mathrm{MO}$, and also the innovation performance that should be evaluated. It is quite plausible in theory that the true effects of $M O$ can be more closely ascertained in relation to innovation performance since these are more likely to result from a greater understanding of customers' needs, competitors' strategies and the market sensing.

We suggest that high-tech firms should strive to improve their $M O$ so as to increase their technologically-based product quality, which in turn can lead to superior innovation performance. In sum, service innovation strongly influences innovation performance in a high-tech industry. Traditionally, the scenarios of innovation performance in high-tech firms include those of R\&D inputs (Wang 20II), new product development (Rothaermel and Deeds 2004), technological innovation capabilities (Yam et al. 20I I), and technology acquisition (Tsai and Wang 2008). We recognize that the idea of recommending high-tech firms to actively invest in these resources of innovation performance may sound ill-advised because there is considerable overlap between each of these resources (Hagedoorn and Cloodt 2003), leaving very little space for breakthrough in innovation performance. However, it should be noted that our finding suggest service innovation exerts a significant impact on product or/and process innovation performance in these high-tech firms. This finding provides us with a better understanding of the sources of innovation performance in the high-tech firms and highlights the need to analyze the service innovation and innovation performance together.

Previous $M O$ research suggested that the $M O$ are implemented and determined their performance (Gotteland and Boulé 2006; Rodríguez-Pinto et al. 20I I; Agarwal et al. 2003). In contrast, our study indicates that the effects of $\mathrm{MO}$ are not straightforward and it is not sufficient to examine the presence or absence of innovation performance. Specifically, our analytical service innovation also helps to refine the argument that the link between $\mathrm{MO}$ and innovation performance is likely to be mediated by service innovation. Managers must recognize that a failure to include service innovation will present an incomplete picture of the determinants of innovation performance. Relational capital theory (Kale et al. 2000) provides a possible explanation for this finding. High-tech firm investment in a customer relationship network allows for successful access to, and usage of, new information that exists in the social network, which informs managers of customer future desires. Thus, high-tech firms can recognize the need to develop service innovation to satisfy customer needs in a timely manner (Alam and Perry 2002).

Dynamic capability (DC) (Teece 2007) supports the possible explanation for another finding of the mediating role of service innovation in the link between competitor orientation and innovation performance. DC addresses how competences are renewed over time so as to provide innovative responses to competitor's strategy changes.A hightech firm operated in a turbulent competitive environment, which was characterized by unpredictable interaction with multiple competitors. An important outcome of competitor orientation is to secure the necessary competitor's information in order to ensure a frontier rather than a follower of service innovation (Ottesen and Grønhaug 2004). Thus, we suggests that high-tech firms would also try to adjust their strategy and focus appropriately, depending on the contexts in which their service innovation activities superior to those of competitors.

The main question addressed in this study is, "Does service innovation matter in the high-tech industry?" Our study provides clear evidence to rationalize and design a service innovation system that promotes customer orientation and competitor orientation. Furthermore, after customer orientation and competitor orientation have been successfully implemented, managers need to focus on incorporating these two sub-constructs of $\mathrm{MO}$ into service innovation; thereby driving innovation performance.

\section{Limitations and future research}

Our study presents a first step toward further understanding service innovation in the high-tech industry and the study limitations suggest the need for additional research. First, since the sample for this research is drawn from the database of top Taiwanese I,000 manufacturing firms, the applicability of these findings to other countries in developed 
countries should be considered with caution. Future research within high-tech firms from a wider variety of countries is necessary to generalize the findings further. Secondly, this study is based on the management-reported assessments of MO, but the evaluation of the high-tech firm's MO may be more significantly evaluated by customers. Future research is needed to assess whether MO using customeroriented assessment may be a better indicator.

Thirdly, while our study focuses on $\mathrm{MO}$ as it relates to innovation performance, additional managerial characteristics may contributes to innovation performance. Future research may therefore include other antecedents of innovation performance such as organization learning (Alegre and Chiva 2008), alliance partners (Wang 20II), and intellectual capital (Hsu and Wang 20I2). Fourth, although our study provides new insights on how service innovation in related to enhancing innovation performance, it does not address how innovation triggered a change in the levels of innovation performance. Hence, future research explicitly conducting qualitative research (e.g., in-depth case studies) is needed to better understand how the service innovation strategies changed overtime.

These limitations aside, the current study represents a significant step in service innovation. In response to the call for research or service innovation within high-tech industry, our study not only examines how MO and service innovation contribute to innovation performance, but also reveals that service innovation mediates the effectiveness of $\mathrm{MO}$ in innovation performance.

\section{Appendix}

Innovation performance $[\alpha=0.89 ; \mathrm{CR}=0.82 ; \mathrm{AVE}=0.57]$

I. Our company significantly improves existing services in terms of their basic characteristics and promotes them to the market.

2. Our company introduces new services into the market.

3. Our company develops new product attributes. (deleted)

4. Our company develops new components.

5. Our company improves the level of automations.

6. Our company uses new energy sources.

Service innovation $[\alpha=0.86 ; C R=0.85 ; A V E=0.62]$

I. Our company totally developed new services.

2. Our company improved new services.

3. Our company repositioned existing services.

4. Our company extended its existing service line.

5. Our company offered new features that competitors do not offer in the market.

6. Our company tried to change the customers' behavior by offering new services.

\section{Market orientation}

Customer orientation $[\alpha=0.89 ; \mathrm{CR}=0.78 ; \mathrm{AVE}=0.5 \mathrm{I}]$

I. We periodically revise our products to ensure they respond to what our customers want.

2. We supply our customers with complete information so they can obtain the best performance from our products.

3. Information on the satisfaction felt by customers is systematically distributed to all the activities in the company. 4. We meet periodically with our customers in order to find out what products they will need in the future. (deleted)

Inter-functional orientation $[\alpha=0.90 ; C R=0.89 ; A V E=0.59$ ]

I. Any information that from the market is distributed throughout all departments and levels of the company. 2. Staff from the different activities in our company meet periodically for joint planning of responses to changes that are taking place in the business environment.

3. We share resources with other departments in the company.

4. All of managers in the company understand how the company can contribute to creating customer value. (deleted)

Competitor orientation $[\alpha=0.87 ; \mathrm{CR}=0.84 ; \mathrm{AVE}=0.56]$

I. Our salespeople regularly share information within our business concerning competitors' strategies.

2. We target customers with whom we can develop a competitive advantage. (deleted)

ISSN: 07 I8-2724. (http://www.jotmi.org) 
3. Senior managerial staff discusses the strengths and weaknesses of our competitors with other managers in the company.

4. When somebody in the company has important information about competitors, they quickly alert staff in other departments.

\section{About auhor}

Chao-Hung Wang is a professor of management at Ling Tung University, Taiwan. His current research interests are in the area of technology management, relationship marketing and dynamic modeling. His papers have been published in the British Journal of Management, Technological Forecasting and Social Change, Asia Pacific Management Review, Service Business, Tourism Management, African Journal of Business Management, Expert Systems with Applications, Journal of Electronic Commerce Research and others.

\section{References}

ABRAMOVICl, M. Bancel-charensol, L. (2004). How to take customers into consideration in service innovation projects. The Service Industries Journal, 24, 56-78.

ADNER, R. Levinthal, D. (200I). Demand heterogeneity and technology evolution: implications for product and process innovation. Management Science, 47, 6I I-628.

AGARWAL, S., Erramilli, M. K., Dev, C. S. (2003). Market orientation and performance in service firms: role of innovation. Journal of Services Marketing, 17, 68-82.

AKMAN, G., Yilmaz, C. (2008). Innovative capability, innovation strategy and market orientation: an empirical analysis in Turkish software industry. International Journal of Innovation Management, 12,69-1 II.

ALAM, I. (2006). Service innovation strategy and process: a cross-national comparative analysis. International Marketing Review, 23, 234-254.

ALAM, I., Perry, C. (2002). A customer-oriented new service development process. Journal of Services Marketing, 16, 5I 5 534.

ALDAS-MANZANO, J., Ster, K. I.,Vila, N. (2005). Market orientation and innovation: an inter-relationship analysis. European Journal of Innovation Management, 8, 437-452.

ALEGRE, J., Chiva, R. (2008). Assessing the impact of organizational learning capability on product innovation performance: An empirical test. Technovation, 28, 315-326.
AMARA, N., Landry, R., Traor, N. (2008). Managing the protection of innovations in knowledge-intensive business services. Research policy, 37, I530-I547.

ARMBRUSTER, H., Bikfalvi, A., Kinkel, S., Lay, G. (2008). Organizational innovation: The challenge of measuring nontechnical innovation in large-scale surveys. Technovation, 28, 644-657.

ARMSTRONG, J., Overton, T. (1977). Estimating nonresponse bias in mail surveys. Journal of marketing research, 14, 396-402.

ATUAHENE-GIMA, K. (1996). Market orientation and innovation. Journal of Business Research, 35, 93-103.

ATUAHENE-GIMA, K. (1996). Differential potency of factors affecting innovation performance in manufacturing and services firms in Australia. Journal of Product Innovation Management, I3, 35-52.

AUGUSTO, M., Coelho, F. (2009). Market orientation and new-to-the-world products: Exploring the moderating effects of innovativeness, competitive strength, and environmental forces. Industrial Marketing Management, 38, 94-108.

AUH, S., Menguc, B. (2005). Top management team diversity and innovativeness: The moderating role of interfunctional coordination. Industrial Marketing Management, 34, 249-26I.

AVLONITIS, G. J., Papastathopoulou, P. G., Gounaris, S. P. (200I).An empirically-based typology of product innovativeness for new financial services: Success and failure scenarios. Journal of Product Innovation Management, 18, 324-342.

BAKER, W. E., Sinkula, J. M. (1999). The synergistic effect of market orientation and learning orientation on organizational performance. Journal of the academy of marketing science, $27,4 \mid \mathrm{I}-427$.

BAKER, W. E., Sinkula, J. M. (2007). Does market orientation facilitate balanced innovation programs? An organizational learning perspective. Journal of Product Innovation Management, 24, 316-334.

BATESON, J. E., Hoffman, K. D. (20I I). Services Marketing, 5th ed., South-Western.

BENDAPUDI, N., Leone, R. P. (2003). Psychological implications of customer participation in co-production. Journal of marketing, | 4-28. 
BENNER, M. J., Tushman, M. L. (2003). Exploitation, exploration, and process management: The productivity dilemma revisited.Academy of Management Review, 28, 238-256.

BLAZEVIC, V., Lievens, A. (2008). Managing innovation through customer coproduced knowledge in electronic services: An exploratory study. Journal of the Academy of Marketing Science, 36, |38-I5I.

CAMBRA-FIERRO, J., Florin, J., Perez, L., Whitelock, J. (20I I). Inter-firm market orientation as antecedent of knowledge transfer, innovation and value creation in networks. Management Decision, 49, 444-467.

CASSIMAN, B., Veugelers, R. (2006). In search of complementarity in innovation strategy: internal R\&D and external knowledge acquisition. Management Science, 52, 68-82.

CHANG,Y. C., Chang, H.T., Chi, H. R., Chen, M. H., Deng, L. L., (20I2). How do established firms improve radical innovation performance? The organizational capabilities view. Technovation, $32,44 I-45 I$.

CHEN, J. S., Tsou, H. T., Ching, R. K. (20II). Co-production and its effects on service innovation. Industrial Marketing Management, 40, I331-1346.

CHENG, C. C., Krumwiede, D. (20I2). The role of service innovation in the market orientation-new service performance linkage. Technovation, 32, 487-497.

DESHPAND, R., Farley, J. U., Webster JR, F. E. (1993). Corporate culture, customer orientation, and innovativeness in Japanese firms: a quadrad analysis. Journal of Marketing, 2337.

DESS, G. G., Robinson, R. B. (1984). Measuring organizational performance in the absence of objective measures:The case of the privately-held firm and conglomerate business unit. Strategic Management Journal, 5, 265-273.

FLINT, D. J., Woodruff, R. B., Gardial, S. F. (2002). Exploring the phenomenon of customers' desired value change in a business-to-business context. Journal of Marketing, I02-I I7.

GATIGNON, H., Xuereb, J. M. (1997). Strategic orientation of the firm and new product performance. Journal of Marketing Research, 77-90.

GEBAUER, H., Edvardsson, B., Bjurko, M. (2010). The impact of service orientation in corporate culture on business performance in manufacturing companies. Journal of Service Management, 21, 237-259.
GEBAUER, H., Fleisch, E., Friedli, T. (2005). Overcoming the service paradox in manufacturing companies. European Management Journal, 23, 14-26.

GOTTELAND, D., Boul, J. M. (2006). The market orientation-new product performance relationship: Redefining the moderating role of environmental conditions. International Journal of Research in Marketing, 23, I7I-I85.

GRONROOS, C. (1990). Relationship approach to marketing in service contexts: The marketing and organizational behavior interface. Journal of Business Research, 20, 3-II.

HAGEDOORN, J., Cloodt, M. (2003). Measuring innovative performance: is there an advantage in using multiple indicators? Research Policy, 32, I365-1379.

HAIR, J. F., Anderson, R. E., Tatham, R.L., Black, W. C. (2006). Multivariate Data Analysis, 5th ed., London: Prentice-Hall.

HARMAN, H. H. (1976). Modern factor analysis, University of Chicago Press.

HIPP, C., Grupp, H. (2005). Innovation in the service sector: The demand for service-specific innovation measurement concepts and typologies. Research Policy, 34, 517-535.

HSU, L. C., WANG, C. H. (20I2). Clarifying the effect of intellectual capital on performance: the mediating role of dynamic capability. British Journal of Management, 23, 179-205.

HULT, G. T. M., Ketchen, D. J. (200 I). Does market orientation matter?: A test of the relationship between positional advantage and performance. Strategic Management Journal, 22, 899-906.

JAW, C., Lo, J.Y., Lin, Y. H. (20I0). The determinants of new service development: Service characteristics, market orientation, and actualizing innovation effort. Technovation, 30, 265-277.

JAWORSKI, B.J., Kohli,A. K. (I993). Market orientation: antecedents and consequences. Journal of Marketing, 53-70.

JIM NEZ-JIMENEZ, D., Valle, R. S., Hernandez-Espallardo, M. (2008). Fostering innovation: the role of market orientation and organizational learning. European Journal of Innovation Management, II, 389-4I2.

KALE, P., Singh, H., Perlmutter, H. (2000). Learning and protection of proprietary assets in strategic alliances: building relational capital. Stratic Management Journal, 2 I (3): 21 7-237. 
KANDEMIR, D., Yaprak, A., Cavusgil, S.T. (2006). Alliance orientation: conceptualization, measurement, and impact on market performance. Journal of the Academy of Marketing Science, 34, 324-340.

KEEBLE, D. (1997). Small firms, innovation and regional development in Britain in the 1990s. Regional Studies, 31, 28I293.

KESKIN, H. (2006). Market orientation, learning orientation, and innovation capabilities in SMEs:An extended model. European Journal of Innovation Management, 9, 396-4I7.

KIRCA,A. H., Jayachandran, S., Bearden,W. O. (2005). Market orientation: a meta-analytic review and assessment of its antecedents and impact on performance. Journal of Marketing, 24-4I.

KOHLI, A. K., Jaworski, B. J. (1990). Market orientation: the construct, research propositions, and managerial implications. Journal of Marketing, I- I8.

LAFORET, S. (2009). Effects of size, market and strategic orientation on innovation in non-high-tech manufacturing SMEs. European Journal of Marketing, 43, 188-212.

LAURSEN, K., Salter,A. (2006). Open for innovation: the role of openness in explaining innovation performance among UK manufacturing firms. Strategic Management Journal, 27, $|3|-\mid 50$.

LAY, G., Copani, G., Ger, A., Biege, S. (2010). The relevance of service in European manufacturing industries. Journal of Service Management, 2I, 7I5-726.

LI, H. L., Tang, M. J. (20I0). Vertical integration and innovative performance: The effects of external knowledge sourcing modes. Technovation, 30, 40 I-4I0.

LIU, X., Buck, T. (2007). Innovation performance and channels for international technology spillovers: Evidence from Chinese high-tech industries. Research Policy, 36, 355-366.

LUKAS, B. A., Ferrell, O. (2000). The effect of market orientation on product innovation. Journal of the Academy of Marketing Science, 28, 239-247.

MENTION, A. L. (20I I). Co-operation and co-opetition as open innovation practices in the service sector:Which influence on innovation novelty? Technovation, 3I, 44-53.
MICHEL, S., Brown, S.W., Gallan, A. S. (2008). An expanded and strategic view of discontinuous innovations: deploying a service-dominant logic. Journal of the Academy of Marketing Science, 36, 54-66.

MOLLER, K., Rajala, R., Westerlund, M. (2008). Service innovation myopia? A new recipe for client-provider value creation. California Management Review, 50, 31.

MORGAN, R. E., Berthon, P. (2008). Market Orientation, Generative Learning, Innovation Strategy and Business Performance Inter-Relationships in Bioscience Firms. Journal of Management Studies, 45, I 329-I 353.

MULLER, E., Zenker,A. (200I). Business services as actors of knowledge transformation: the role of KIBS in regional and national innovation systems. Research Policy, 30, I50I-1516.

NARVER, J. C., Slater, S. F. (1990). The effect of a market orientation on business profitability. Journal of Marketing, 20-35. NUNNALLY, J. C., Bernstein, I. H. (1994). Psychometric theory, New York: McGraw-Hill.

OTTESEN, G. G., NHAUG, K. (2004). Exploring the dynamics of market orientation in turbulent environments: a case study. European Journal of Marketing, 38, 956-973.

OVERVIK, O.T.,Welo, T. (20I I). Maximizing product innovation through adaptive application of user-centered methods for defining customer value. Journal of Technology Management \& Innovation, 6, I72-192.

PASWAN, A., D'souza, D., Zolfagharian, M. A. (2009). Toward a contextually anchored service innovation typology. Decision Sciences, 40, 5I 3-540.

PODSAKOFF, P. M., MACKENZIE, S. B., LEE J.Y. Podsakoff, N. P. (2003). Common Method Bias in Behavioral Research: A Critical Review of the Literature and Recommended Remedies. Journal of Applied Psychology, 85, 879-903.

RODR, G. P., Carbonell, R. P., Guez-Escudero, A. I. (20II). Speed or quality? How the order of market entry influences the relationship between market orientation and new product performance. International Journal of Research in Marketing, 28, I 45-I 54.

ROTHAERMEL, F.T., Deeds, D. L. (2004). Exploration and exploitation alliances in biotechnology:A system of new product development. Strategic Management Journal, 25, 20I-22I.

SANTAMAR, A, L., NIETO, J. M., MILES, I. (2012). Service innovation in manufacturing firms: Evidence from Spain. Technovation, 32, I44-I55. 
SIN, L. Y., Alan, C., Yau, O. H., Lee, J. S., Chow, R. (2002). The effect of relationship marketing orientation on business performance in a service-oriented economy. Journal of Services Marketing, 16, 656-676.

SLATER, S. F., Narver, J. C. (1994). Does competitive environment moderate the market orientation-performance relationship? Journal of Marketing, 46-55.

SONG, L. Z., Song, M., Di Benedetto, C. A. (2009). A Staged Service Innovation Model. Decision Sciences, 40, 57I-599.

SPOHRER, J., Maglio, P. P. (2008). The Emergence of Service Science: Toward Systematic Service Innovations to Accelerate Co-Creation of Value. Production and Operations Management, 17, 238-246.

STRAUB,T., Kohler, M., Hottum, P.,Arrass,V.,Welter, D. (20I3). Customer Integration in Service Innovation:An Exploratory Study. Journal of Technology Management \& Innovation, 8, 25-33.

SUNDBO, J.. Gallouj, F. (2000). Innovation as a loosely coupled system in services. International Journal of Services Technology and Management, I, I5-36.

TEECE, D. J. (2007). Explicating dynamic capabilities: the nature and microfoundations of (sustainable) enterprise performance. Strategic Management Journal, 28, I 3 I9-1350.

TSAI, K. H. (2009). Collaborative networks and product innovation performance: Toward a contingency perspective. Research Policy, 38, 765-778.

TSAI, K. H.,WANG, J. C. (2008). External technology acquisition and firm performance: A longitudinal study. Journal of Business Venturing, 23, 91-I I 2.

TSIOTSOU, R. H. (20I0). Delineating the effect of market orientation on services performance: a component-wise approach. The Service Industries Journal, 30, 375-403.

V ZQUEZ, R., Santos, M. L., Álvarez, L. I. (200I). Market orientation, innovation and competitive strategies in industrial firms. Journal of Strategic Marketing, 9, 69-90.

VANDERMERWE, S., Rada, J. (1989). Servitization of business: adding value by adding services. European Management Journal, 6, 3|4-324.

VARGO, S. L., Lusch, R. F. (2004). The four service marketing myths remnants of a goods-based, manufacturing model. Journal of Service Research, 6, 324-335.
VARGO, S. L., Lusch, R. F. (2008). From goods to service (s): Divergences and convergences of logics. Industrial Marketing Management, 37, 254-259.

VOON, B. H. (2006). Linking a service-driven market orientation to service quality. Managing Service Quality, 16, 595619.

WANG, C. H. (20II). The moderating role of power asymmetry on the relationships between alliance and innovative performance in the high-tech industry. Technological Forecasting and Social Change, 78, I268-1279.

WANG, C. H., Hsu, L. C. (20I4). Building exploration and exploitation in the high-tech industry: The role of relationship learning. Technological Forecasting \& Social Change, 8I, 33I-340.

XAVIER MOLINA-MORALES, F., Teresa Mart Nez-Fern Ndez, M.,Torl,V.J. (20I I).The dark side of trust: the benefits, costs and optimal levels of trust for innovation performance. Long Range Planning, 44, I I8-I 33.

YAM, R., Lo,W., Tang, E. P., Lau, A. K. (20I I).Analysis of sources of innovation, technological innovation capabilities, and performance: An empirical study of Hong Kong manufacturing industries. Research Policy, 40, 391-402.

ZENG, S. X., Xie, X., Tam, C. (20I0). Relationship between cooperation networks and innovation performance of SMEs. Technovation, 30, I8I-194.

ZHOU, K. Z., Brown, J. R., Dev, C. S. (2009). Market orientation, competitive advantage, and performance: A demandbased perspective. Journal of Business Research, 62, 10631070.

ZHOU, K. Z., Kin, C., Tse, D. K. (2005). The effects of strategic orientations on technology-and market-based breakthrough innovations. Journal of Marketing, 42-60. 